\section{Reduced Rates of Glyphosate in Combination with 2,4-D and Dicamba Impact Sweetpotato Yield}

\author{
Donnie K. Miller ${ }^{1}$, Thomas M. Batts ${ }^{1}$, Josh T. Copes ${ }^{1}$, \\ and David C. Blouin ${ }^{1,2}$
}

AdDitional INDEX wORDs. crop injury, crop response, herbicide drift, Ipomoea batatas, reduced rates, sprayer contamination

Summary. Commercialization of crops tolerant to application of 2, 4-dichlorophenoxyacetic acid $(2,4-\mathrm{D})$ and dicamba is a cause of major concern for sweetpotato (Ipomoea batatas) producers regarding potential negative impacts due to herbicide drift or sprayer contamination events. A field study was initiated in 2016 and repeated in 2017 to assess impacts of reduced rates of combinations of glyphosate with 2,4-D or dicamba on sweetpotato growth and production. Reduced rates of $1 / 10 x, 1 / 33 x, 1 / 66 x$, and 1/100x of a $1 x$ rate of glyphosate at $1 \mathrm{lb} /$ acre plus 2,4-D choline at $0.94 \mathrm{lb} /$ acre and glyphosate at $1 \mathrm{lb} /$ acre plus diglycolamine salt of dicamba at $0.5 \mathrm{lb} /$ acre were applied to 'Beauregard' sweetpotato at 10 or 30 days after transplanting. With respect to visual injury, in general glyphosate plus dicamba proved to be more injurious than glyphosate plus 2,4-D, especially within the lower rate range. In most cases injury was greater at the later application timing. In either case, typical hormonal herbicide symptomology was quite evident 35 days after application. With respect to U.S. No. 1 and total (U.S. No. 1, canner, and jumbo grade) sweetpotato yield, greatest negative impact was observed with herbicide application at the upper rate range, particularly the $1 / 10$ and $1 / 33 x$ rates, and at the later application timing regardless of herbicide applied.

$\mathrm{I}$ n 2018, Louisiana ranked fourth in production acreage of sweetpotato behind North Carolina, Mississippi, and California (LSU AgCenter, 2019). That year Louisiana harvested 7682 acres of sweetpotato with an estimated yield of 491 50 -lb bushels per acre, resulting in $\$ 94.5$ million in total production value (LSU AgCenter, 2019). Production and packing fresh market costs were about $\$ 4000 /$ acre to $\$ 4600 /$ acre, while production costs for the processing sector was about $\$ 2300$ /acre before storage (LSU AgCenter, 2019). Given this high level of production costs, there is little margin for error in terms of factors

Received for publication 20 Dec. 2019. Accepted for publication 9 Mar. 2020.

Published online 14 April 2020.

${ }^{1}$ LSU AgCenter Northeast Research Station, P.O. Box 438, St. Joseph, LA 71366

${ }^{2}$ LSU Department of Experimental Statistics, 161 M.D. Woodin Hall, Baton Rouge, LA 70803

Funding for this project was provided by the Louisiana Sweetpotato Commission.

D.K.M. is the corresponding author. E-mail: dmiller@ agcenter.lsu.edu.

This is an open access article distributed under the CC BY-NC-ND license (https://creativecommons.org/ licenses/by-nc-nd/4.0/).

https://doi.org/10.21273/HORTTECH04562-19
Lateral root development is fundamentally dependent on auxin signaling, and anything that interferes with this process interferes with storage root formation. This is the precise window for targeting negative impacts, such as herbicide injury, to determine maximum potential to reduce yield due to reduction in storage root number (A. Villordon, personal communication).

With increasing populations of weeds resistant to glyphosate herbicide, variety development has shifted focus to developing new product formulation technologies with older herbicides and using plant genetic modification to combat such populations. Two new technologies have been commercialized that allow application of 2,4-D choline (in combination with glyphosate) or diglycolamine (DGA)/N,N-Bis(3-aminopropyl) methylamine (BAPMA) salt of dicamba (3,6-dichloro-2-methoxybenzoic acid) (alone or in combination with glyphosate) over the top of crops that were previously intolerant to these two herbicides. Soybean (Glycine max), cotton (Gossypium hirsutum), and corn (Zea mays) varieties with these traits are readily available for purchase and use by producers. Dicamba and 2,4-D selectively control most dicotyledonous plants including morningglory (Ipomoea sp.) (Siebert et al., 2004), palmer amaranth (Amaranthus palmeri) (Norsworthy et al., 2008), and marestail (Conyza candensis) (Bruce and Kells, 1990), and therefore are more commonly used in monocotyledonous crops, such as pastures, turf, and in some instances corn and small grains. These new technologies use plant genetic resistance to these products so that applications may be made directly to the transformed crops.

Merchant et al. (2013) found that morningglories, when exposed to either $2,4-\mathrm{D}$ at $1.2,1.75$, or 2.3 $\mathrm{L} \cdot \mathrm{ha}^{-1}$, or dicamba at $0.6,1.2$, and 2.3 $\mathrm{L} \cdot \mathrm{ha}^{-1}$, were completely controlled. Glyphosate applied at $1120 \mathrm{~g} \cdot \mathrm{ha}^{-1}$ controlled 2- to 5 - $\mathrm{cm}$ entireleaf ( I moea hederacea) and pitted morningglory (Ipomoea lacunosa), while the same species at 8 to $10 \mathrm{~cm}$ were controlled $84 \%$ and $88 \%$, respectively (Corbett et al., 2004). Because sweetpotato is also an Ipomoea species, off target movement of 2,4-D, dicamba, and glyphosate is a major cause for concern to producers. Research has 
shown sweetpotato to be highly sensitive to $2,4-\mathrm{D}$, with a very low concentration of only 100 ppm considered optimum to induce flowering (Mutasa et al., 2013). Previous research has shown that $1 / 4$ of the recommended rate of 2,4-D applied at $27 \mathrm{~d}$ after transplant will result in complete kill of 'Beauregard' sweetpotato within 2 weeks (Clark and Braverman, 1998). At a similar rate, dicamba and triclopyr resulted in chlorosis and severe stunting of plants. Dicamba, 2,4-D, and triclopyr at $1 / 4$ and $2,4-D$ at $1 / 10$ of the recommended use rate evaluated resulted in almost nonexistent yield, while dicamba and 2,4-D applied at $1 / 100$ of the use rate resulted in intermediate yield reduction. Clark and Braverman (1998) also demonstrated that stored roots from plants treated with dicamba at $1 / 10$ of the use rate produced shoots with epinastic symptomology 8 months after application. In a separate study, Clark and Braverman in 1998 also reported that glyphosate applied at $1 / 2,1 / 4$, and $1 / 10$ of the use rate $27 \mathrm{~d}$ after transplant reduced 'Beauregard' U.S. No. 1 and total marketable yield. When applied at $4 \mathrm{l}$ d after transplant, yield reduction was observed only with the $1 / 2$ and $1 / 4 x$ rates. Myers et al. in 2017 also indicated negative impacts with regards to injury and yield to sweetpotato exposed to simulated glyphosate drip rates encountered in wick weed control applications 4 to 8 weeks after planting.

No research has been conducted on the potential impacts on sweetpotato from 2,4-D (applied as Enlist Duo; Corteva Agriscience, Wilmington, DE) and dicamba (applied as Roundup Xtend; formerly Monsanto Company, St. Louis, MO) herbicide formulations that will be available for use in the Enlist or Xtend cropping systems. Off-target movement or sprayer contamination of 2,4-D, dicamba, or glyphosate is a major cause for concern. With this concern in mind, research was conducted in Louisiana to 1) determine differences in sweetpotato susceptibility to 2,4-D or dicamba applied at differing rates; 2) evaluate impact of reduced rates of these hormonal herbicides and glyphosate that may be encountered in off-target or sprayer contamination events; and 3 ) determine the impact of application timing on growth and yield of sweetpotato.

\section{Materials and methods}

A field study was initiated in 2016 at the Sweetpotato Research Station near Chase, LA and repeated in 2017. 'Beauregard' sweetpotato was mechanically transplanted 29 June 2016 and 5 July 2017 using standard industry practices on a 40 inch row with 12 -inch in-row plant spacing, resulting in 13,068 plants/ acre. Soil classification is a Gigger silt loam (fine-silty, mixed, active, thermic Typic Fragiudalfs) with an organic matter content of $1.5 \%$ to $1.8 \%$ and $\mathrm{pH}$ 5.8. This variety was chosen as it encompassed most acreage planted in Louisiana (M. Sistrunk, personal communication). To eliminate weed interference, flumioxazin at $0.063 \mathrm{lb} /$ acre pre-transplant, followed by $S$-metolachlor at $1.25 \mathrm{lb} /$ acre immediately post-transplant, were applied to all plots (LSU AgCenter, 2020). Subsequent applications of clethodim at $0.152 \mathrm{lb} /$ acre were applied throughout the growing season as needed for grass control (LSU AgCenter, 2020). Additional hand-weeding was performed as needed for broadleaf weed control. Fertilizer was applied pre-plant at 40 $\mathrm{lb} /$ acre nitrogen $(\mathrm{N}), 110 \mathrm{lb} /$ acre phosphorous (P), and $112 \mathrm{lb} /$ acre potassium $(\mathrm{K})$. Chlorpyrifos (1.88 $\mathrm{lb} /$ acre $)$ and clothianidin $(0.196 \mathrm{lb} /$ acre) insecticides were applied in furrow before planting (LSU AgCenter, 2020). Plants were monitored during the growing season, and insect control (as well as overhead irrigation) was scheduled as needed.

A randomized complete block experimental design with four replications was used. Treatments were placed in a factorial arrangement with Factor A consisting of herbicide (glyphosate in combination with 2,4-D or dicamba); Factor B consisting of herbicide rate $(0,1 / 10,1 / 33$, $1 / 66$, and $1 / 100$ of the lx use rate of each product); and Factor $\mathrm{C}$ consisting of application timing [ 10 or 30 $\mathrm{d}$ after transplanting (DAP)]. The $\mathrm{lx}$ use rate of the herbicides used as a basis for reduced rate applications was glyphosate at $1 \mathrm{lb} /$ acre plus 2,4$\mathrm{D}$ choline at $0.94 \mathrm{lb} /$ acre and glyphosate at $1 \mathrm{lb} /$ acre plus DGA salt of dicamba at $0.5 \mathrm{lb} /$ acre. Additional spray adjuvants were not included with herbicide treatments. Plots were three rows $10 \mathrm{ft}$ wide by $25 \mathrm{ft}$ long. Two rows were treated leaving the third as a border row.

Treatments were applied at a constant $15 \mathrm{gal} /$ acre carrier volume at 28 psi using a compressed air tractor-mounted sprayer equipped with air induction nozzles. Previous researchers evaluating impacts of reduced rates of herbicides on other crops have reported increased injury when carrier volumes are varied proportionally with lower herbicide rates (Ellis et al., 2002; Roider et al., 2008). Other researchers, however, have suggested that proportionally reducing carrier volume with herbicide rate may yield unrealistic results and confound the results obtained (Everitt and Keeling, 2009; Marple et al., 2008). Visual ratings of plant injury based on a scale of 0 (no effect) to 100 (plant death) were recorded at $7,14,28$, and $35 \mathrm{~d}$ after treatment (DAT). Chlorosis, necrosis, leaf strapping and cupping, and height reduction were all factored when determining visual injury estimates. A single row from all plots was mechanically harvested, and sweetpotatoes were separated into U.S. No. 1, canner, or jumbo categories to determine yield. These grades are determined based on U.S. Department of Agriculture standards (U.S. Department of Agriculture, 2005).

The MIXED procedure of SAS (version 9.4; SAS Institute, Cary, NC) was used for all data analysis. The fixed effect for the model for yield data were treatment (herbicide, rate, and application timing). The fixed effects for the model for injury data were treatment and repeated measures effects for DAT. The random effects for all models were year and replications. Protected least significant difference tests were used for mean separation. The significance level was 0.05 for all tests.

\section{Results and discussion}

Sweetpotato InJury. Repeated measures analysis did not allow for pooling of crop injury data across rating intervals. Statistical analysis indicated significant interactions involving herbicide by herbicide rate, by rating interval; and herbicide by application timing, by rating interval. Therefore, crop injury data are 


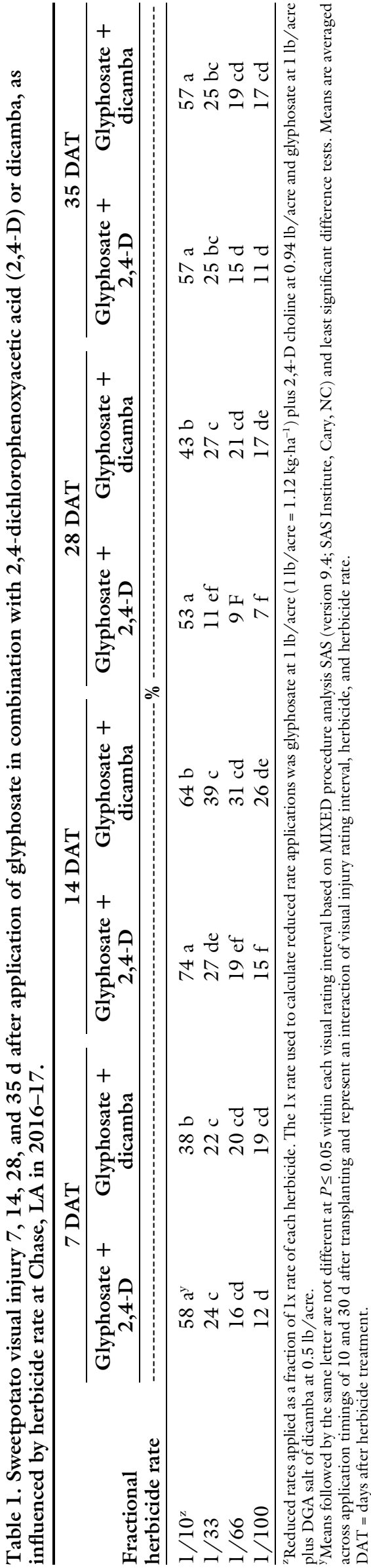

reported separately for each rating interval.

At 7 DAT, averaged across application timing, the only herbicide rate where herbicide difference was noted for crop injury was at the $1 /$ $10 \mathrm{x}$ rate where injury was greater with glyphosate plus $2,4-\mathrm{D}$ (58\% vs. $38 \%$ ) (Table 1). Crop injury at all other reduced rates ranged from $12 \%$ to $24 \%$. For each herbicide, injury was greatest at the $1 / 10 \mathrm{x}$ rate. Averaged across herbicide rate, the only application timing where herbicide difference was noted was at $30 \mathrm{DAP}$, with greater crop injury following application of glyphosate plus $2,4-\mathrm{D}$ (35\% vs. $27 \%$ ) (Table 2 ). Crop injury was greater at the 30 DAP compared with 10 DAP application timing for glyphosate plus 2,4 -D (35\% vs. $21 \%$ ) but not glyphosate plus dicamba $(22 \%$ and $27 \%$, respectively).

At 14 DAT, averaged across application timing, crop injury was greater following application of glyphosate plus 2,4-D at the 1/ $10 \mathrm{x}$ rate $(74 \%$ vs. $64 \%)$ but greater following application of glyphosate plus dicamba at lower application rates of $1 / 33 \times(39 \%$ vs. $27 \%), 1 /$ 66x (31\% vs. $19 \%)$ and $1 / 100 x$ x $(26 \%$ vs. $15 \%)$ (Table 1). Greatest injury was observed for both herbicides at the $1 / 10 x$ rate, while the $1 / 33 x$ rate resulted in greater injury than the 1/100x rate. Averaged across herbicide rate, the only application timing where a difference in herbicide was noted was at $10 \mathrm{DAP}$, with greatest injury following application of glyphosate plus dicamba (37\% vs. $24 \%$ ) (Table 2). For both glyphosate plus $2,4-\mathrm{D}(43 \%$ vs. $24 \%)$ and glyphosate plus dicamba $(43 \%$ vs. $37 \%)$, crop injury was greater at the later application timing.

At 28 DAT, averaged across application timing, crop injury was greater following application of glyphosate plus 2,4-D at the $1 /$ $10 \mathrm{x}$ rate $(53 \%$ vs. $43 \%)$ but greater following application of glyphosate plus dicamba at lower application rates of $1 / 33 x(27 \%$ vs. $11 \%), 1 /$ $66 \mathrm{x}(21 \%$ vs. $9 \%)$ and $1 / 100 x(17 \%$ vs. $7 \%$ ) (Table 1). For glyphosate plus $2,4-\mathrm{D}$, crop injury was greatest at the $1 / 10 \mathrm{x}$ rate $(53 \%$ vs. $7 \%$ to $11 \%)$. For glyphosate plus dicamba, crop injury was greatest at the 1/ $10 x$ rate $(43 \%)$, while the $1 / 33 x$ rate resulted in $27 \%$ injury, which was equal to injury with the $1 / 66$ x rate $(21 \%)$ and greater than that for the lowest rate (17\%). Averaged across herbicide rates, glyphosate plus dicamba resulted in greater injury at both the $10(14 \%$ vs. $6 \%)$ and $30(40 \%$ vs. $33 \%)$ DAP application timings (Table 2). For each herbicide, crop injury was greatest at the later timing.

At 35 DAT, averaged across application timing, crop injury ranged from $11 \%$ and $17 \%$ at the lowest rate, to $57 \%$ at the highest rate following application of glyphosate plus 2,4-D and glyphosate plus dicamba, respectively, with no difference noted among herbicides (Table 1). For glyphosate plus 2,4-D, crop injury was greatest at the $1 / 10 \mathrm{x}$ herbicide rate $(57 \%)$, while the $1 / 33 x$ rate resulted in $25 \%$ injury, which was greater than lower rates $(11 \%$ and 15\%). For glyphosate plus dicamba, the highest herbicide rate of $1 / 10 x$ resulted in $57 \%$ crop injury, which was greater than the equivalent injury observed with all other rates applied ( $17 \%$ to $25 \%$ ). Averaged across herbicide rates, a difference in crop injury in respect to herbicide applied was not noted at either application timing; and injury for both glyphosate plus 2,4-D and glyphosate plus dicamba was greater at the 30 DAP timing in comparison with the 10 DAP timing ( $44 \%$ vs. $10 \%$ and $43 \%$ vs. $16 \%$, respectively (Table 2).

An abundance of research has been conducted to determine the effects of reduced rates of 2,4-D and dicamba that simulate rates encountered in off-target applications in crops other than sweetpotato. In North Carolina, dicamba and 2,4-D were both observed to cause significant yield reduction in soybean at rates as low as $1 / 8$ of the labeled use rate (Johnson et al., 2012). In the same study, it was determined that dicamba caused greater visual injury than 2,4-D applied at similar fractional rates. Cotton exposed to $1 / 8$ recommended use rate of $2,4-\mathrm{D}$ or dicamba exhibited injury between $40 \%$ to $60 \%$ and $60 \%$ to $80 \%$ for 1 and 2 weeks after treatment, respectively (Johnson et al., 2012). Application of $2,4-\mathrm{D}$ at $1 / 200$ the recommended use rate on three- to four-leaf cotton resulted in $76 \%$ (2005) and $88 \%$ (2006) injury $28 \mathrm{~d}$ after treatment (Marple et al., 2008). 


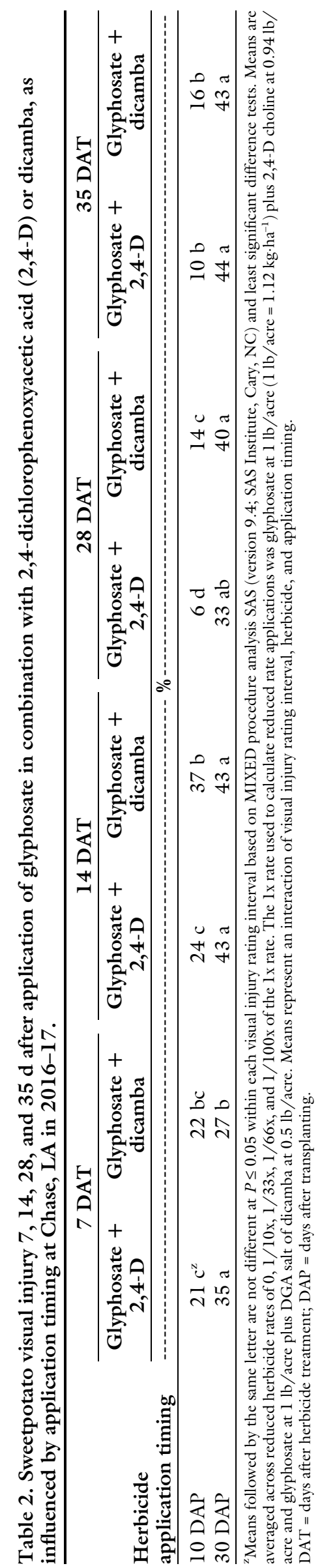

When exposed to $1 / 50$ of the normal use rate of $2,4-\mathrm{D}$, plants such as pepper (Capsicum sp.), tomato (Solanum lycopersicum), and squash (Cucurbita pepo) were injured 35\%, $41 \%$, and $49 \%$, respectively (Merchant et al., 2012). Similar injury responses were observed with sweetpotato in the current research. Greater injury at the later application timing could simply be because the plants were larger and had greater leaf/stem surface area to intercept more of the herbicide spray solution. Although differences in response between 2,4-D and dicamba were not observed with respect to negative impacts on sweetpotato [or positive impact (greater control) on morningglory in previously cited research within this article], dicamba was generally more injurious than $2,4-\mathrm{D}$, and this result is attributed to possible inherent tolerance differences in the variety.

Sweetpotato yield. Statistical analysis indicated a significant herbicide rate by application timing interaction for all yield grade categories except canner. With respect to canner yield, significant herbicide by herbicide rate and herbicide by application timing interactions were observed.

Averaged across herbicides, at the 10 DAP application timing U.S. No. 1 yield was significantly reduced in comparison with no herbicide $(0$ rate) only, with the highest reduced rate $(209 \mathrm{bu} / \mathrm{acre}$ vs. $139.1 \mathrm{bu} /$ acre) (Table 3 ). At the 30 DAP application timing, U.S. No. 1 yield was significantly reduced $84 \%$ and $45 \%$ with the $1 / 10 x$ and $1 / 33 x$ rates, respectively. Within each reduced rate, U.S. No. 1 yield difference in application timing was noted only with the $1 / 10 x(139.1$ bu/acre vs. $33.1 \mathrm{bu} / \mathrm{acre})$ and $1 / 33 \mathrm{x}(219.9$ bu/acre vs. $111.9 \mathrm{bu} / \mathrm{acre}$ ) rates where yield was lower at the later timing.

Averaged across application timing, within each herbicide, canner grade yield was reduced only in comparison with no herbicide with glyphosate plus 2,4-D applied at the highest rate of $1 / 10 \mathrm{x}(63 \mathrm{bu} / \mathrm{acre}$ vs. $147 \mathrm{bu} /$ acre) (Table 3). Within each reduced rate, a difference in herbicide was only noted at the $1 /$ 10x rate, with a lower yield observed with glyphosate plus 2,4-D (108 bu/acre vs. 63 bu/acre). Averaged across herbicide rate, glyphosate plus 2,4-D applied 10 DAP resulted in a $21 \%$ lower canner grade yield than when applied 30 DAP (data not shown). Yield was similar among application timings with glyphosate plus dicamba. At $10 \mathrm{DAP}$, canner grade yield was greater following application of glyphosate plus 2,4-D, in comparison with glyphosate plus dicamba (149 bu/acre vs. $125 \mathrm{bu} /$ acre), while no herbicide difference was noted at the later application timing (data not shown).

Averaged across herbicides, at the 30 DAP application timing, Jumbo grade yield was significantly reduced $30 \%$ to $65 \%$ in comparison with no herbicide (0 rate), with all herbicide rates except the lowest reduced rate (Table 3 ). At the 10 DAP application timing, yield was not significantly reduced. Within each reduced rate, yield differences in application timing were noted only with the $1 / 10 \mathrm{x}$ (109 bu/acre vs. 48.9 bu/acre) and 1/66x (162.1 bu/acre vs. $98.8 \mathrm{bu} / \mathrm{acre}$ ) rates where yield was lower at the later timing.

Averaged across herbicides, at the $10 \mathrm{DAP}$ application timing, total yield (U.S. No. 1, canner, and jumbo) was significantly reduced in comparison with no herbicide ( 0 rate) only, with the highest reduced rate $(444$ bu/acre vs. $344 \mathrm{bu} /$ acre) (Table 3 ). At the 30 DAP application timing, yield was significantly reduced $66 \%$, $27 \%$, and $15 \%$, with the $1 / 10 x, 1 /$ $33 x$, and $1 / 66 x$ rates, respectively. Within each reduced rate, total yield difference in application timing was noted only with the $1 / 10 \mathrm{x}$ ( $344 \mathrm{bu} /$ acre vs. $157.9 \mathrm{bu} / \mathrm{acre}$ ) and $1 / 33 \mathrm{x}$ (455.9 bu/acre vs. $338 \mathrm{bu} /$ acre) rates where yield was lower at the later timing.

Negative yield impacts with 2,4$\mathrm{D}$ and dicamba have been observed in other crops. In Kansas, research has shown that at $1 / 3$ of the use rate, dicamba can cause dead soybean shoot tips at 20 DAT and recovery by $45 \mathrm{DAT}$, as well as a minimum $75 \%$ yield reduction when applied to two to three-trifoliate soybean (Al-Khatib and Peterson, 1999). In North Carolina, dicamba and 2,4-D were both observed to cause significant yield reduction in soybean at rates as low as $1 / 8$ of the labeled use rate (Johnson et al., 2012). In Louisiana, when 
Table 3. Sweetpotato yield in bu/acre) following application of glyphosate in combination with plus 2,4dichlorophenoxyacetic acid $(2,4-\mathrm{D})$ or dicamba, as influenced by application timing and/or herbicide rate at Chase, LA in 2016-17.

\begin{tabular}{|c|c|c|c|c|c|c|c|c|}
\hline \multirow{4}{*}{$\begin{array}{l}\text { Fractional } \\
\text { herbicide rate }\end{array}$} & \multirow{2}{*}{\multicolumn{2}{|c|}{ U.S. No. 1}} & \multirow{2}{*}{\multicolumn{2}{|c|}{ Jumbo }} & \multirow{2}{*}{\multicolumn{2}{|c|}{ Total $^{\mathrm{z}}$}} & \multicolumn{2}{|c|}{ Canner } \\
\hline & & & & & & & \multirow{2}{*}{$\begin{array}{c}\text { Glyphosate }+ \\
2,4-\mathrm{D}\end{array}$} & \multirow{2}{*}{$\begin{array}{c}\text { Glyphosate }+ \\
\text { dicamba }\end{array}$} \\
\hline & $10 \mathrm{DAP}$ & 30 DAP & $10 \mathrm{DAP}$ & $30 \mathrm{DAP}$ & $10 \mathrm{DAP}$ & 30 DAP & & \\
\hline & \multicolumn{8}{|c|}{ - } \\
\hline $0^{y}$ & $209 \mathrm{ab}^{\mathrm{x}}$ & $203.1 \mathrm{ab}$ & $100.1 \mathrm{bcd}$ & $140.8 \mathrm{ab}$ & $444 \mathrm{ab}$ & $461.1 \mathrm{a}$ & $147 \mathrm{a}$ & $130 \mathrm{ab}$ \\
\hline $1 / 10$ & $139.1 \mathrm{~cd}$ & $33.1 \mathrm{e}$ & $109 \mathrm{bcd}$ & $48.9 \mathrm{e}$ & $344 \mathrm{c}$ & $157.9 \mathrm{~d}$ & $63 c$ & $108 \mathrm{~b}$ \\
\hline $1 / 33$ & $219.9 \mathrm{a}$ & $111.9 \mathrm{~d}$ & 89.9 cde & $68 \mathrm{de}$ & $455.9 \mathrm{ab}$ & $338 c$ & $155.9 \mathrm{a}$ & $132.9 \mathrm{ab}$ \\
\hline
\end{tabular}

${ }^{\mathrm{z}}$ Total yield represents a combination of yield of U.S. No. 1, jumbo, and canner grades. These grades are determined based on U.S. Department of Agriculture (USDA) standards: https://www.ams.usda.gov/grades-standards/sweetpotatoes-grades-and-standards

${ }^{\mathrm{y}}$ Reduced rates applied as a fraction of $\mathrm{lx}$ rate of each herbicide. The $\mathrm{lx}$ rate used to calculate reduced rate applications was glyphosate at $1 \mathrm{lb} / \mathrm{acre}\left(\mathrm{llb} / \mathrm{acre}=1.12 \mathrm{~kg} \cdot \mathrm{ha} \mathrm{a}^{-1}\right)$ plus 2,4-D choline at $0.94 \mathrm{lb} /$ acre and glyphosate at $1 \mathrm{lb} /$ acre plus DGA salt of dicamba at $0.5 \mathrm{lb} /$ acre.

${ }^{\mathrm{x}}$ Means followed by the same letter are not different at $P \leq 0.05$ within each sweetpotato yield grade based on MIXED procedure analysis SAS (version 9.4 ; SAS Institute, Cary, NC) and least significant difference tests. Means are averaged across herbicides glyphosate $+2,4-\mathrm{D}$ and glyphosate + dicamba (U.S. No. 1, jumbo, and total) or application timings of 10 and $30 \mathrm{~d}$ after transplanting (canner). One $50-\mathrm{lb}(22.7 \mathrm{~kg}) \mathrm{bu} / \mathrm{acre}=56.043 \mathrm{~kg} \cdot \mathrm{ha}^{-1}$.

$\mathrm{DAP}=$ days after transplanting.

exposed to $1 / 2$ the labeled rate of dicamba at the two to three-trifoliate stage, a yield reduction of $85 \%$, as well as a height reduction of $72 \%$ was observed in soybean (Griffin et al., 2013). When applied at four- to fiveleaf cotton, $1 / 2$ the use rate of dicamba resulted in a $36 \%$ lint yield reduction (Everitt and Keeling, 2009). 'Norland' potato (Solanum tuberosum L.) has been observed to exhibit phytotoxic symptomology following application of dicamba, ranging from $2.8 \mathrm{~g} \cdot \mathrm{ha}^{-1}$ to $22.2 \mathrm{~g} \cdot \mathrm{ha}^{-1}$ (Wall 1994). Wall (1994) also found that at $22.2 \mathrm{~g}$ a.i./ha, marketable yield lost equaled $70 \%$ to $75 \%$. When exposed to $1 / 50$ of the normal use rate of 2,4-D, plants such as pepper, tomato, and squash were injured $35 \%$, $41 \%$, and $49 \%$, respectively, and yield was reduced by $51 \%, 23 \%$, and $27 \%$, respectively (Merchant et al., 2012). In addition, rates as low as $1 / 400$ of the use rate resulted in a $14.5 \%$ yield reduction of pepper. Previous research has shown that $1 / 4$ of the recommended rate of 2,4-D applied at $27 \mathrm{~d}$ after transplant will result in complete kill of 'Beauregard' sweetpotato within 2 weeks (Clark and Braverman, 1998). At a similar rate, dicamba and triclopyr resulted in chlorosis and severe stunting of plants. Dicamba, 2,4-D, and triclopyr at $1 / 4$ and $2,4-\mathrm{D}$ at $1 / 10$ of the recommended use rate evaluated resulted in almost nonexistent yield, while dicamba and 2,4-D applied at $1 / 100$ of the use rate resulted in intermediate yield reduction. Clark and Braverman (1998) also demonstrated that stored roots from plants treated with dicamba at $1 / 10$ of the use rate produced shoots with epinastic symptomology 8 months after application. In a separate study, Clark and Braverman in 1998 also reported that glyphosate applied at $1 / 2,1 / 4$, and $1 / 10$ of the use rate $27 \mathrm{~d}$ after transplant reduced 'Beauregard' U.S. No. 1 and total marketable yield. When applied at $4 \mathrm{l} \mathrm{d}$ after transplant, yield reduction was observed only with the $1 / 2$ and $1 / 4 x$ rates. Myers et al., in 2017, also indicated negative impacts with regards to injury and yield to sweetpotato exposed to simulated glyphosate drip rates encountered in wick weed control applications 4 to 8 weeks after planting.

Although no individual storage root average sample weights were recorded for each yield grade, visual observation of harvest storage roots indicated very minimal malformation or consistently "smaller" storage roots within each yield grade in the current research. Also early season visual injury rating differences between 2,4-D and dicamba, where the latter appeared to be more injurious, were not manifested in differences in yield reduction, indicating the crop is able to recover from dicamba injury to impact yield on similar levels to that observed with 2,4-D. Data collected cannot allow for an explanation of the precise reason for negative yield impacts (reduced photosynthetic capacity, slowed root development, etc.).
In conclusion, in general, glyphosate plus dicamba proved to be more injurious than glyphosate plus 2,4-D, particularly within the lower rate range. In most cases, injury was greater at the later application timing, presumably due to larger plants having greater surface area for herbicide interception. In either case, typical hormonal herbicide symptomology (leaf epinasty) was quite evident $35 \mathrm{~d}$ after application. Of interest is that early season visual injury differences among herbicides was not manifested in differences in yield following application, regardless of herbicide rate or application timing. With respect to U.S. No. I and total (U.S. No. 1, canner, and jumbo grade) sweetpotato yield, the greatest negative impact was observed with herbicide application at the upper rate range, particularly the $1 / 10$ and $1 / 33 x$ rates, and at the later application timing regardless of herbicide applied. Therefore, sweetpotato producers with multicrop farming operations are cautioned to thoroughly follow all sprayer cleanout procedures when previously spraying one of the combination herbicides evaluated, or to devote different equipment to spraying Xtend and Enlist crops. In addition, proper consideration should be given to planting these crops near sweetpotato production fields and making herbicide applications; under environmental conditions that are not conducive to off-target spray movement. 


\section{Literature cited}

Al-Khatib, K. and D. Peterson. 1999. Soybean (Glycine max) response to simulated drift from selected sulfonylurea herbicides, dicamba, glyphosate and glufosinate. Weed Technol. 13:264-270.

Bruce, J.A. and J.J. Kells. 1990. Horseweed (Conyza canadensis) control in notillage soybeans (Glycine max) with preplant and preemergence herbicides. Weed Technol. 4:642-647.

Clark, C.A. and M.P. Braverman. 1998. Herbicide damage on Beauregard. Tater Talk, 4 .

Corbett, J.L., S.D. Askew, W.E. Thomas, and J.W. Wilcut. 2004. Weed efficacy evaluations for bromoxynil, glufosinate, glyphosate, pyrithiobac and sulfosate. Weed Technol. 18:443-453.

Ellis, J.M., J.L. Griffin, and C.A. Jones. 2002. Effect of carrier volume on corn (Zea mays) and soybean (Glycine max) response to simulated drift of glyphosate and glufosinate. Weed Technol. 16:587592.

Everitt, J.D. and J.W. Keeling. 2009. Cotton growth and yield response to simulated 2,4-D and dicamba drift. Weed Technol. 23:503-506.

Griffin, J.L., M.J. Bauerle, D.O. Stephenson, IV., D.K. Miller, and J.M. Boudreaux. 2013. Soybean response to dicamba applied at vegetative and reproductive stages. Weed Technol. 27:696-703.

Johnson, V.A., L.R. Fisher, D.L. Jordan, K.E. Edmisten, A.M. Stewart, and A.C. York. 2012. Cotton, peanut, and soybean response to sublethal rates of dicamba, glufosinate, and 2,4-D. Weed Technol. 26:195-206.

LSU AgCenter. 2019. Louisiana summary agriculture and natural resources (2018). Pub. 2382, 10/19 Rev. 26 Nov. 2019. <https://www.lsuagcenter.com/ / m edia / sys te m / 7/9/6/7/ 796773af58d4c3e610063c7a8f7985fl/ pub2382\%20ag\%20summary\%202018_ fullpdf.pdf>.

LSU AgCenter. 2020. Sweet potatoes. 10 Feb. 2020. <https://www.lsuagcenter. $\mathrm{com} /$ topics/crops/sweet_potatoes $>$.

Marple, M.E., K. Al-Khatib, and D.E. Peterson. 2008. Cotton injury and yield as affected by simulated drift of 2,4-D and dicamba. Weed Technol. 22:609-614.

Merchant, R.M., A.S. Culpepper, L.M. Sosnoskie, E.P. Prostko, J.S. Richburg, and T.M. Webster. 2012. Fruiting vegetable and cucurbit response to simulated drift rates of 2,4-D. Proc. South. Weed Sci. Soc. 65:10

Merchant, R.M., L.M. Sosnoskie, A.S. Culpepper, L.E. Steckel, A.C. York, L.B. Braxton, and J.C. Ford. 2013. Weed response to 2,4-D, 2,4-DB, and dicamba applied alone or with glufosinate. J. Cotton Sci. 17:212-218.

Mutasa, W., E. Gasura, S. Mabasa, R.T. Masekesa, and R. Masvodza. 2013. Does 2,4-D induce flowering in sweetpotato? Afr. J. Biotechnol. 12(51):7057-7062.

Myers, S.L., K.M. Jennings, and D.W. Monks. 2017. Sweetpotato response to simulated glyphosate wick drip. Weed Technol. 31:130-135.
Norsworthy, J.K., G.M. Griffith, R.C. Scott, K.L. Smith, and L.R. Oliver. 2008. Confirmation and control of glyphosateresistant palmer Amaranth (Amaranthus palmeri) in Arkansas. Weed Technol. 22:108-113.

Roider, C.A., J.L. Griffin, S.A. Harrison, and C.A. Jones. 2008. Carrier volume affects wheat response to simulated glyphosate drift. Weed Technol. 22:453-458.

Siebert, J.D., J.L. Griffin, and C.A. Jones. 2004. Red Morningglory (Ipomoea coccinea) control with 2,4-D and alternative herbicides. Weed Technol. 18:38-44.

U.S. Department of Agriculture. 2005. United States standards for grades of sweetpotatoes. U.S. Department Agriculture, Washington DC. 26 Nov. 2019. <http://www.ams.usda.gov/sites/ default/files/media/Sweetpotato_ Standard\%5Bl\%5D.pdf>.

Villordon, A., I. Ginzberg, and N. Firon. 2014. Root architecture and root and tuber crop productivity. Trends Plant Sci. 19:1-7.

Villordon, A., D.R. LaBonte, and N. Firon. 2009. Development of a simple thermal time method for describing the onset of morpho-anatomical features related to sweetpotato storage root formation. Scientia Hort. 121:374-377.

Wall, D.A. 1994. Potato (Solanum tuberosum) response to simulated drift of dicamba, clopyralid, and tribenuron. Weed Sci. 42:110-114. 